\title{
Matrix Tablets from Algerian Lyophilized Berries (LB) (Arbutus unedo L.) Date (Phoenix dactylifera L.)
}

Tounsia Abbas-Aksil $^{1 *}$, Moussa Abbas ${ }^{2}$, Mohamed Trari ${ }^{3}$ and Salem Benamara ${ }^{1}$

${ }^{1}$ Research Laboratory in Food Technology (LRTA) Faculty of Engineering Science University M'hamed Bougara 35000 Boumerdès, Algeria

${ }^{2}$ Laboratory of Soft Technologies and Biodiversity (LTDVPMB/F S), University M'hamed Bougara 3500 Boumerdès, Algeria

${ }^{3}$ Labotory of Storage and Valorization of Renewable Energies, Faculty of chemistry (USTHB) BP 32-16111 El-Alia, Bab Ezzouar, Algeria

\begin{abstract}
The present study aimed to elaborate matrix tablets from powder mixture (2:1 ratio) of Algerian date (Phoenix dactylifera L.) fruit and lyophilized berries (Arbutus unedo L.) (LB), using the direct compression technique. In a first part, the physicochemical properties, including the X-ray diffraction, of individual powders and their mixture were determined. In the second step, the swelling, erosion and in vitro release rate characteristics of tablets were studied. The dissolution study of tablets is evaluated throughout the electric conductivity (EC) of surrounding medium (distilled water). Among the four tested models, namely zero-order, first-order, Higuchi and Korsmeyer-Peppas, the latter seems to be the most appropriate $\left(R^{2}=0.972-0.989\right)$ to describe kinetics of the ionic transfer whatever the applied temperature. Further, the activation energy $(17.272 \mathrm{~kJ} / \mathrm{mol})$ related to the transfer mechanism is obtained from the Arrhenius plot with a correlation coefficient greater than 0.899 . Globally, the physicochemical parameters of obtained tablets were found to be in compliance with the pharmacopoeial standards.
\end{abstract}

Keywords: Arbutus berries; Date fruit; Tablet; Electric conductivity; Dissolution; Model

\section{Introduction}

The use of wild plants as food source is well known in all countries of the world, particularly during the periods of war and /or drought. Currently, the research results highlight the significance of the wild edible plants as cheap source of nutrients $[1,2]$ which can explain the interest for using these species as dietary supplements [3]. However, many in vivo studies have evaluated the beneficial effect of the plants on human health.

Wild edible fruits were found to have significant amounts of bioactive compounds, including polyphenols and flavonoids [4]. The high quantities of anthocyanins and natural pigments make them potential candidates for functional food statute [5]. In this context, some wild fruits in India have been identified to have better nutritional value than cultivated fruits [6]. The richness of the wild fruit in valuable ingredients as Iron, Sodium, Potassium, Zinc and Calcium indicate the scope of using wild edible fruits for dietary supplement $[7,8]$.

The Mediterranean region is rich of locally grown, wild and semiwild edible fruit plants. The strawberry tree (Arbutus unedo L.) is one of the typical Mediterranean wild trees, growing in mountains, heavy clay and dry soils, on siliceous and decarbonated substrata [9]. In fresh form, its berry fruits are always incorporated into yogurts and used as confectionaries for pie, pastry fillings and cereal products [10]. After processing, they are also employed for the production of alcoholic beverages, jams, jellies and marmalades [10,11]. Like other plants which are fitted with wonderful defense system assured by various biopharmaceuticals [12], the berries are also known to be used in folk medicine as antiseptic, diuretic and laxative and against cardiovascular pathologies [9]. Wild fruit of Arbutus unedo L. is rich in numerous nutriments specially Calcium, Phosphorus and Potassium [13]. Its sugar content is about $0.47 \mathrm{~g} / \mathrm{g}$ dry basis $(\mathrm{db})$ of which sacchararose $(87.7 \pm 0.6 \mathrm{~g}$ per $\mathrm{kg}$ of dry fruit) and fructose $(208$ $\pm 2 \mathrm{~g}$ per kg of dry fruit) are the major carbohydrates in the unripe and ripe stage, respectively [14]. Strawberry tree fruits are a good source of antioxidants [15], including carotenoids, flavonoids, anthocyanin and ellagic acid. Then proanthocyanidins accounting for more than $80 \%$ of the total flavonoid in arbutus [14-16]. On the other hand, Rodríguez et al. [17] have earlier reported that the higher antioxidant potential of the arbutus berries may be due to the activity of various bioactive components, including vitamin $\mathrm{C}$. In this context, the reducing power of the strawberry tree fruits was found to be one of the highest, among 27 Algerian fruits [18]. So, considering the dietary ingredient, any herbal or botanical material containing vitamins and minerals [19], arbutus berries may be listed as a dietary supplement.

In the last decade, many food products are processed and commercialized in powder form, whereas scientific investigations of various foods powder properties remain insufficient despite their importance in the engineering field [20]. In addition, studies about tableting properties of whole fruits are very scarce: date (Phoenix dactylifera L.) [21], guava and pitaya [22], chebula [23], baobab [24] and mango [25].

The main objective of the present study concerns the tableting ability of the powder mixture (2:1 ratio) of Algerian date (Phoenix dactylifera L.) fruit and lyophilized berries (Arbutus unedo L.) (LB), using the direct compression technique. Some preliminary results have been already communicated and published [26,27].

\section{Materials and Methods}

\section{Fruits and fruit powders}

Fully ripe berries were randomly picked at various trees in Kabylie region (North Algeria) during the winter 2013. The fruit was submitted to freeze drying at $-64^{\circ} \mathrm{C}$ under vacuum $(4.5 \mathrm{~Pa})$ during $48 \mathrm{~h}$, using lyophilizer Type (Christ Alpha1-4LD), provided with vacuum pump (RZ 6, max pressure $0.04 \mathrm{~Pa}$ ). The dried product is ground, sieved (sieve

*Corresponding author: Tounsia Abbas-Aksil, Research Laboratory in Food Technology (LRTA) Faculty of Engineering Science University M'hamed Bougara 35000 Boumerdès, Algeria, Tel: +213554637886; E-mail: tounsiaiap@gmail.com

Received February 15, 2016; Accepted February 22, 2016; Published February 29 2016

Citation: Abbas-Aksil T, Abbas M, Trari M, Benamara S (2016) Matrix Tablets from Algerian Lyophilized Berries (LB) (Arbutus unedo L.) Date (Phoenix dactylifera L.). Nat Prod Chem Res 4: 207. doi:10.4172/2329-6836.1000207

Copyright: (C) 2016 Abbas-Aksil T, et al. This is an open-access article distributed under the terms of the Creative Commons Attribution License, which permits unrestricted use, distribution, and reproduction in any medium, provided the original author and source are credited. 
of type Euromatest-Sintoo, NFX11-501) to obtain powder with particle diameters $(200 \leq \varnothing \leq 400) \mu \mathrm{m}$ and then kept in closed glass flask at $4^{\circ} \mathrm{C}$.

Mech-Degla date fruits were purchased from Boumerdès city (50 $\mathrm{km}$ east Algiers). The dates were first cleaned, pitted and cut in small size pieces that were dried at $(40 \pm 1)^{\circ} \mathrm{C}$ in laboratory oven (type MELAG 405) until a constant weight was reached. The date powder (DP) $(200 \leq \varnothing \leq 400) \mu \mathrm{m}$ is kept into a hermitic glass at $4^{\circ} \mathrm{C}$.

The particle size distribution, Fourier transform infrared spectroscopy (FTIR) and X-ray diffraction (XRD) of LB, DP and DP/LB mixture were investigated using Malvern Mastersizer 2000 laser diffraction analyzer, FTIR Spectra 2000 (Perkin Elmer) and diffractometer (Panalytical Xpert Pro ${ }^{\circledR}$.) respectively.

\section{Physicochemical properties of powders}

The three powder types DP, LB and DP/LB (2:1 ratio) mixture were characterized first for their bulk $\left(\rho_{\text {bulk }}\right)$ and tapped $\left(\rho_{\mathrm{tab}}\right)$ densities, according to the European Pharmacopoeia [28] by means of an apparatus of type ERWEKA (Engelsmann, Germany).

The Carr index (CI) [29] and the Hausner (HR) ratio [30] were calculated using the following equations:

$$
\begin{aligned}
& \mathrm{CI}(\%)=\left(\frac{\rho_{\text {tap }}-\rho_{\text {bulk }}}{\rho_{\text {tap }}}\right) \\
& \mathrm{HR}=\left(\frac{\rho_{\text {tap }}}{\rho_{\text {bulk }}}\right)
\end{aligned}
$$

The flow rate $(\mathrm{g} / \mathrm{s})$ was determined by measuring the time $(\mathrm{t})$ of passage of $100 \mathrm{~g}$ of powder through a standardized glass funnel as described by the European Pharmacopoeia [28]:

Flow rate $(\mathrm{g} / \mathrm{s})=\mathrm{W} / \mathrm{t}(3)$

At the same time, the angle of repose $(\theta)$ formed by the cone of the powder onto the flat surface at the exit of funnel was expressed by $\arctan (\theta)$

\section{Tablet preparation and basic physical-chemical characterization}

Tablets from DP and LB mixture (2:1 ratio) were obtained by compacting the powder using semi alternative tableting press (Mark ED Frogerai. type OA 307).

Tablets processing and their physical characterization were performed in laboratory of CRD/SAIDAL (Algiers) according to the European Pharmacopoeia [28].

- The hardness of 10 tablets was determined with an automatic hardness tester type Pharma Test.

- The friability of the tablets was evaluated with a Friabilator of type ERWEKA TA. For weight uniformity test, 20 tablets were randomly selected, weighed and weight variation (\%) was calculated.

- The disintegration time was evaluated on 6 tablets using a disintegrator ERWEKA control ZT 2. The disintegration is considered achieved when 6 tablets are completely disintegrated.

- The swelling ability was quantified through liquid uptake by the tablets which were placed in 3 different liquid mediums (distilled water, $0.1 \mathrm{~N} \mathrm{HCl}$ and phosphate buffer $\mathrm{pH} 6.8$ ) heated at $37^{\circ} \mathrm{C}$.
- The erosion test is immediately performed after the swelling and consists of the determination of the dried weight of wet tablet by drying at $50^{\circ} \mathrm{C}$ during $24 \mathrm{~h}$ according to Adiba et al. and Zea et al. [21,22]. The morphological examination of tablets during their immersion in distilled water was carried out using a digital camera (Sony ${ }^{\circ}$ DCRSX65E).

\section{Modeling of dissolution kinetics}

Dissolution study was performed according to the method described by Yao et al. [31] with some modifications. Glass beakers (500 $\mathrm{mL}$ capacity) containing dissolution medium (distilled water, 0.1 $\mathrm{N} \mathrm{HCl}$ and phosphate buffer $\mathrm{pH}$ 6.8) were placed in a thermostatic magnetic water-bath and stirred at $75 \mathrm{rpm}$. The kinetic of ions release (at $27,37,47$ and $57^{\circ} \mathrm{C}$ ) was investigated by studying the variation of the electric conductivity (EC) of the simulating physiologic media, using CONSORT C863 conduct meter. Only results related to distilled water are presented here. The conductivity measurement to follow the dissolution of tablets was developed by many authors [31-36]. On the other hand, the dissolution phenomenon has been already investigated on the tablets from lyophilized berries, using however other models (Peleg, Singh et al. and Singh and Kulshrestha) (submitted, in second round review).

The electrical conductivity of the solution is directly related to the concentration of ions of solids dissolved in the water. However the total dissolved solids (TDS) is a measure of the combined content of all inorganic and organic substances contained in a liquid solution. The ability of the electrolyte to diffuse from the matrix to the surrounding medium can be measured using a conventional conductimeter or TDS meter. The relationship of TDS and specific conductance can be approximated by following equation:

$$
\text { TDS }=\mathrm{k}_{\mathrm{e}} \mathrm{EC}
$$

The four following models were tested to describe the experimental data

$$
\begin{array}{lc}
\text { Zero-order model [37]: } & \text { TDS }=\operatorname{TDS}_{0+} \mathrm{k}_{0} \mathrm{t} \\
\text { Higuchi model [38]: } & \text { TDS }=\mathrm{TDS}_{0+} \mathrm{k}_{0} \mathrm{t}^{1 / 2} \\
\text { First-order model [39]: } & \operatorname{lnTDS}=\ln ^{\mathrm{T} D S_{0+}} \mathrm{k}_{1} \mathrm{t} \\
\text { Korsmeyerñ Peppas Model [40]: TDS/TDS }{ }_{0=} \mathrm{kt}^{\mathrm{n}}
\end{array}
$$

where $\mathrm{k}_{\mathrm{e}}=0.53$ represents the conversion factor which varies between 0.5 and 0.8 [41], EC $(\mu \mathrm{S} / \mathrm{cm}), T D S$ and TDS are the initial and at any time $(t)$ total dissolved solids $(\mathrm{mg} / \mathrm{L})$, respectively; TDS/TDS is the fraction of the total released solids at time $t ; \mathrm{k}_{0}, \mathrm{k}_{1}, \mathrm{k}_{\mathrm{H}}$ and $\mathrm{k}$ are the kinetics constants that measure the release rate for zero-order, first-order, Higuchi and Korsmeyer-Peppas model, respectively, $\mathrm{n}$ is a diffusional exponent that depends on the release mechanism and the geometry of the system. The value of $\mathrm{n}$ for cylindrical shaped matrices is given in Table 1 [42].

It must be noticed that these models are commonly used to determine the drug release/dissolution profile from solid dosage forms [43].

Finally, the temperature dependence of the constant (k) corresponding for each model was determined from the Arrhenius equation:

$$
\mathrm{k}=\mathrm{k}_{0} \mathrm{e}^{(-\mathrm{Ea} / \mathrm{RT})}
$$

Where $\mathrm{k}_{\mathrm{o}}$ is a pre-exponential factor, Ea the activation energy $(\mathrm{kJ} / \mathrm{mol}), \mathrm{R}$ the universal gas constant $(8.314 \mathrm{~J} / \mathrm{mol} \mathrm{K})$ and $\mathrm{T}$ the 


\begin{tabular}{|l|l|}
\hline Diffusion exposent $(\mathbf{n})$ & Overall solute diffusion mechanism \\
\hline 0.45 & Fickian diffusion \\
\hline $0.45<n<0.89$ & Anomalous (non-Fickian) diffusion \\
\hline 0.89 & Case-II transport \\
\hline $\mathrm{n}>0.89$ & Super case-II transport \\
\hline
\end{tabular}

Table 1: Diffusion exponent and solute release mechanism for cylindrical shape.

thermodynamic temperature $(\mathrm{K})$. The activation energy $E_{a}$ and the constant $k_{0}$ are determined from the slope and intercept of the plot $\ln k$ versus $1 / T$ respectively.

\section{Statistical analysis}

All measurements were performed in triplicate. The statistical analysis of the experimental data was performed using Origin software version 8 . The Goodness of fit of the selected models was evaluated by the correlation coefficient $\left(\mathrm{R}^{2}\right)$, the chi-squared error $\left(\chi^{2}\right)$ and the root mean square error (RMSE):

$$
\begin{aligned}
& \chi 2=\sum_{i=1}^{\mathrm{N}}\left[\frac{\left(\mathrm{X}_{\left.\mathrm{exp}^{-} \mathrm{X}_{\mathrm{cal}}\right)^{2}}\right.}{\mathrm{X}_{\mathrm{cal}}}\right] \\
& \mathrm{RMSE}=\sqrt{1 / \mathrm{N} \sum_{\mathrm{i}=1}^{\mathrm{N}}\left(\mathrm{X}_{\mathrm{cal}}-\mathrm{X}_{\text {exp }}\right)^{2}}
\end{aligned}
$$

Where $X_{\exp }$ is the experimental value, $X_{\text {cal }}$ the value predicted by the model and $\mathrm{N}$ the number of experimental measurements.

\section{Results and Discussion}

\section{Powder properties}

The physical properties of DP, LB and their mixture DP/LB (2:1 ratio) from which tableting is carried out, are summarized in Table 2. The results show that the LB, DP and their mixture possess excellent flowness ability. However, all powders present $\mathrm{CI}, \mathrm{HR}$ and angle of repose values below the required limits i.e., $15 \%, 1.25$ and $40^{\circ}$, respectively $[28,44]$ which facilitate the die cavity filling and tableting process [45]. At the same time, the HR values of DP, LB and DP/LB are lower than those of maize (1.57) and wheat (1.81) starch which were experienced as pharmaceutical excipients in tablet formulation [29], but the found values were comparable to that of Azadirachta indica fruit powder $(\sim 1.41)$ reported by Mehrotra et al. [46] who have also found an angle of repose of $39.55^{\circ}$, higher to that determined in the present work.

The size distributions of the three powders present a similar general shape as that shown in Figure 1. Moreover, from the data of Table 2, the different size expressions $\left(d_{50}, d_{50}\right.$ and $\left.d_{90}\right)$ vary widely, according to the type of powder. In all cases, the values related to DP are higher than those of LB and this can be simply explained by the compositional characteristics of the initial fruits; the DP/LB mixture displays the greatest $d$ value, considering the predominance of DP in the mixture.

The FTIR spectroscopy is known to be a method commonly applied for characterizing food powders [47-49]. The spectra of LB, $\mathrm{DP}$ and (DP/LB) mixtures (Figure 2) attest that there is no appearance or disappearance of peaks in the powder mixture which confirm the absence of any chemical interaction between DP and LB, thus indicating that these powders are compatible [50]. The FTIR spectra also revealed characteristic signals corresponding to various broad and intense bands; in particular, five specific peaks can be mentioned. The intense band in the $3400-3500 \mathrm{~cm}^{-1}$ region is assigned to stretching $(v)$ vibrations of hydroxyl (-OH) group (free and intermolecular hydrogen band), whereas that around $2930 \mathrm{~cm}^{-1}$ is attributed to (C-H) absorption and include $-\mathrm{CH},-\mathrm{CH}_{2}$, and $-\mathrm{CH}_{3}$ stretching and bending vibrations. The peaks in the region $\left(1630-1061 \mathrm{~cm}^{-1}\right)$ are due to vibrations of the carboxylate (-COO-) group and stretching vibrations of $\mathrm{C}-\mathrm{O}-\mathrm{C}$ bonds in ethers or related compounds respectively [51]. In addition, the FTIR spectra shows another specific peak at around $600 \mathrm{~cm}^{-1}$ which could be assigned to stretching $(\mathrm{v})$ of $\left(-\mathrm{CH}_{2}\right)$ and $(-\mathrm{CH})$ groups as previously suggested by Kamil et al. [52] for tomato products.

The XRD patterns of DP, LB and the mixture of powders (DP/LB) are presented in Figure 3. A very broad band with very weak peaks, characteristic of amorphous forms, is observed in the spectrum of LB (Figure 3a). On the contrary, in the case of DP, the diffraction peaks are intense, indicating the presence of a crystalline structure (Figure $3 \mathrm{~b}$ ). We think that the high sugar content of DP may be the principal responsible of the enhanced crystallinity. The XRD pattern of DP/LB mixture (Figure 3c) exhibited peaks corresponding almost perfectly to those of DP. In opposite, LB picks are not clear, being probably masked by the high DP peaks. On top of that, the effects of compression and sample high hygroscopicity probably alter the XRD analysis as reported by Ledur Alles et al. [53] on saccharides powder from yak on roots (Smallanthus sonchifolius). Furthermore, the amorphous characteristics are clearly reported on different dried mango powders [54] and fluidize-dried gum extracted from the fresh fruits of Abelmoschus esculentus [55]. However, Niimura et al. [56] have shown that strawberry flesh has low-crystallinity cellulose I. According

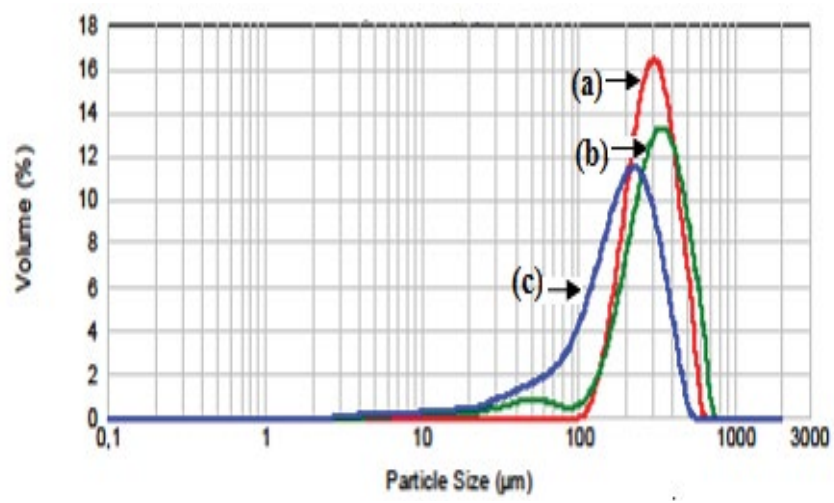

Figure 1: Particle size distribution of powders: (a) DP; (c) LB; (b) DP/LB.

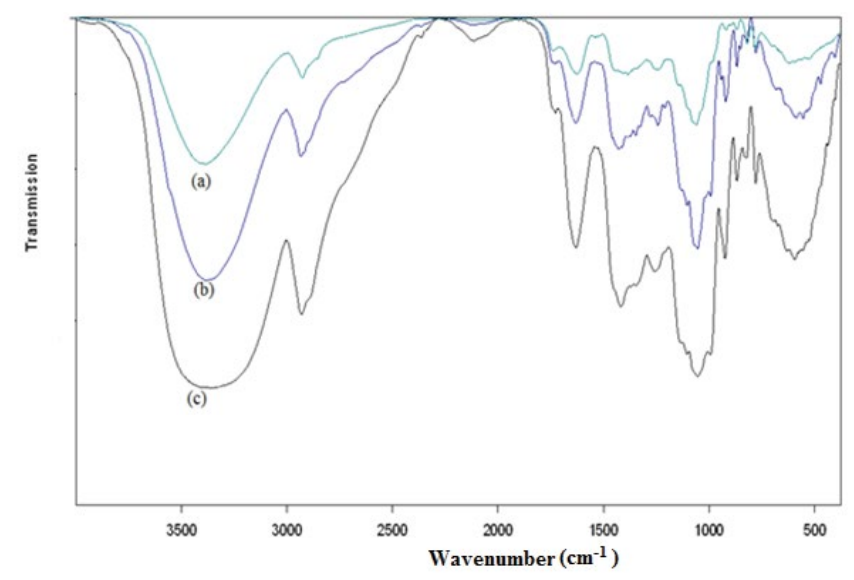

Figure 2: FTIR Spectrum of powders: (a) DP; (b) LB; (c) DP/LB. 


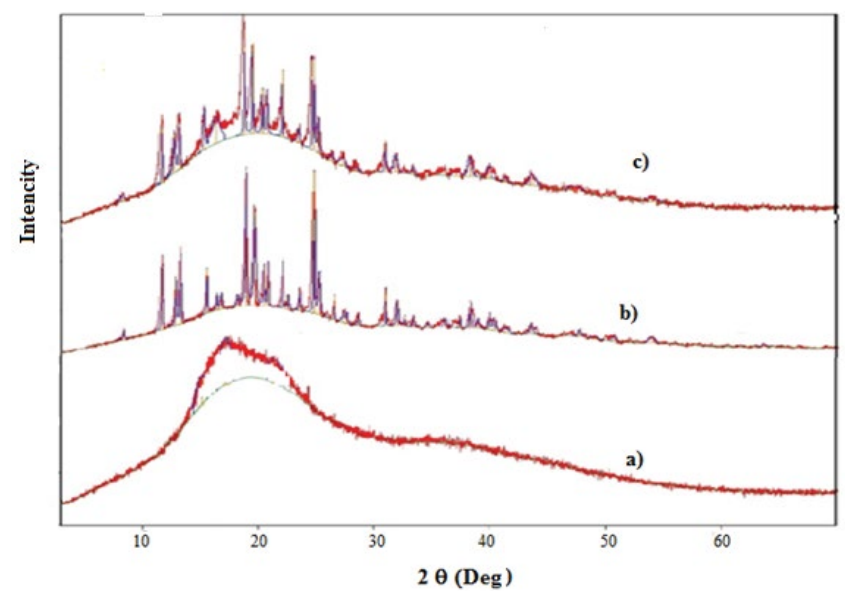

Figure 3: X-ray diffraction patterns of powders: (a) DP; (b) LB; (c) DP/LB.

\begin{tabular}{|l|l|l|l|}
\hline & Ingredients & & \\
\hline Parameters & LB & DP & LB/DP \\
\hline Bulk Density $\left(\mathrm{g} / \mathrm{cm}^{3}\right)$ & $0.431 \pm 0.002$ & $0.535 \pm 0.003$ & $0.438 \pm 0.003$ \\
\hline Tapped Density $\left(\mathrm{g} / \mathrm{cm}^{3}\right)$ & $0.481 \pm 0.004$ & $0.562 \pm 0.005$ & $0.512 \pm 0.003$ \\
\hline Carr's index $(\%)$ & $10.395 \pm 0.005$ & $4.850 \pm 0.014$ & $14.452 \pm 0.005$ \\
\hline Hausner's ratio & $1.116 \pm 0.006$ & $1.050 \pm 0.015$ & $1.169 \pm 0.007$ \\
\hline Angle of repose $\left(^{\circ}\right)$ & $26.400 \pm 0.782$ & $29.93 \pm 0.51$ & $24.740 \pm 0.182$ \\
\hline The flow rate $(\mathrm{g} / \mathrm{s})$ & $10.291 \pm 0.193$ & $9.511 \pm 0.053$ & $8.960 \pm 0.061$ \\
\hline $\mathrm{d}_{10}(\mu \mathrm{m})$ & 62.223 & 183.135 & 147.974 \\
\hline $\mathrm{d}_{50}(\mu \mathrm{m})$ & 190.610 & 294.382 & 310.649 \\
\hline $\mathrm{d}_{90}(\mu \mathrm{m})$ & 341.908 & 453.121 & 518.176 \\
\hline $\mathrm{d}_{\mathrm{n}}=\left(\mathrm{d}_{90}-\mathrm{d}_{10}\right) / \mathrm{d}_{50}$ & 1.467 & 0.917 & 0.714 \\
\hline
\end{tabular}

Date are represented as mean \pm SD $(n=3)$.

$d_{10}, d_{90}$ and $d_{50}$ is the diameter at 10,90 and $50 \%$ undersize respectively; $d_{n}$ used as an indicator of distribution width

Table 2: Properties of formulation ingredients LB, DP and mixed DP and LB (2:1) powder.

to these results, it can be concluded that the crystallinity depends on both the nature of the extract and composition of fruits.

\section{Some physical-chemical characteristics of tablets}

The physical characteristics of prepared tablets are presented in Table 3. Crushing strength test demonstrates the ability of tablets to withstand pressure or stress during handling, packaging and transport. Furthermore, the mechanical strength of tablets determines the disintegration time and the dissolution rate.

The hardness and friability of obtained DP/LB tablets met the minimum requirement to be within the Pharmacopoeial limits ( $>4 \mathrm{kp}$ and $<1 \%$ respectively), thus confirming the ability of LB/DP powder mixture (2:1 ratio) for: i) tableting application without adding any chemical blinder, and ii) withstanding the mechanical shocks during their handling and transport.

The disintegration time (25 min) of the matrix is comparable to that (24 min) found by Niimura et al. [56] about the disintegration of tablets from noni (Morinda Citrifolia, L.) fruit extract added with maltodextrin as sub coating material, and it is less than $(>30 \mathrm{~min})$ that found by Ngwuluka et al. [57] regarding the disintegration of paracetamol tablets added with the dried fruit of date (Phoenix dactylifera $L$.) as an excipient.

\section{Dissolution properties of obtained tablets}

Tablet swelling and erosion studies: Tablet swelling and erosion is a valuable test to better understand the mechanisms of release and the relative importance of participating parameters [58,59].

Matrix tablet erosion and swelling kinetics (Figures 4 and 5) demonstrated a linear increase of both parameters up to $20 \mathrm{~min}$, moreover the Zero-Order equation perfectly fit the experimental data $\left(\mathrm{R}^{2}=0.99\right)$. According to the immersion liquid, the following order of evolution can be establish for erosion and swelling intensities over the dissolution process: distilled water $>$ phosphate buffer $>$ $\mathrm{HCl}$ and phosphate buffer $>\mathrm{HCl}>$ distilled water respectively. The tablets showed a maximum degree of swelling at 24 min whatever the surrounding media. This swelling phenomenon is governed by the osmotic effect whose mechanism is correlated to that already described by Costa et al. [60]; the water migration takes place from less concentrated to the more concentrated solution. Khan et al. [61] suggested that the swelling kinetics of the matrices were an important determinant of drug release. At the same time, the tablets had the highest erosion rate in phosphate buffer which is in correlation with the swelling results. In all media, the dissolution is a balance between swelling and erosion which determines the release process of ions from the fruit tablets. These findings are in agreement with works of Adiba

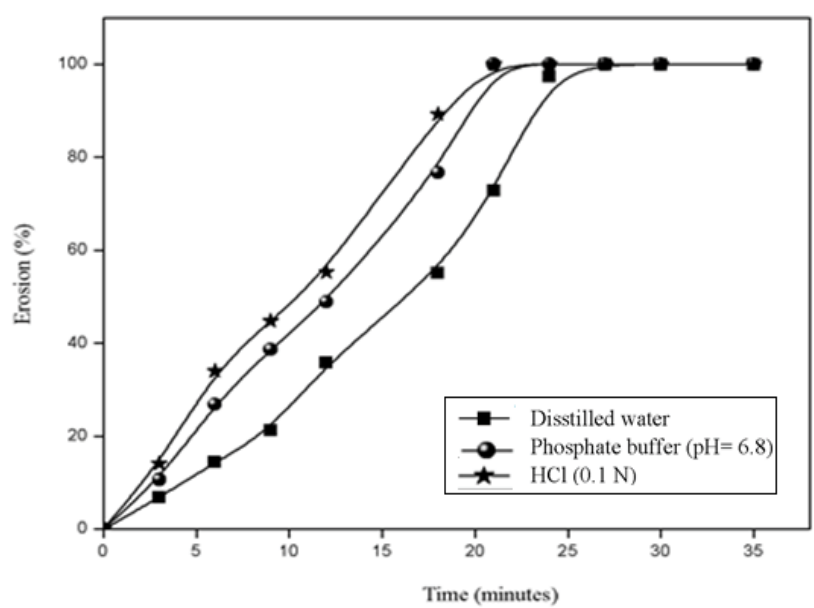

Figure 4: Erosion $\%$ versus immersion time of formulated DP/LB-tablets at $37^{\circ} \mathrm{C}$

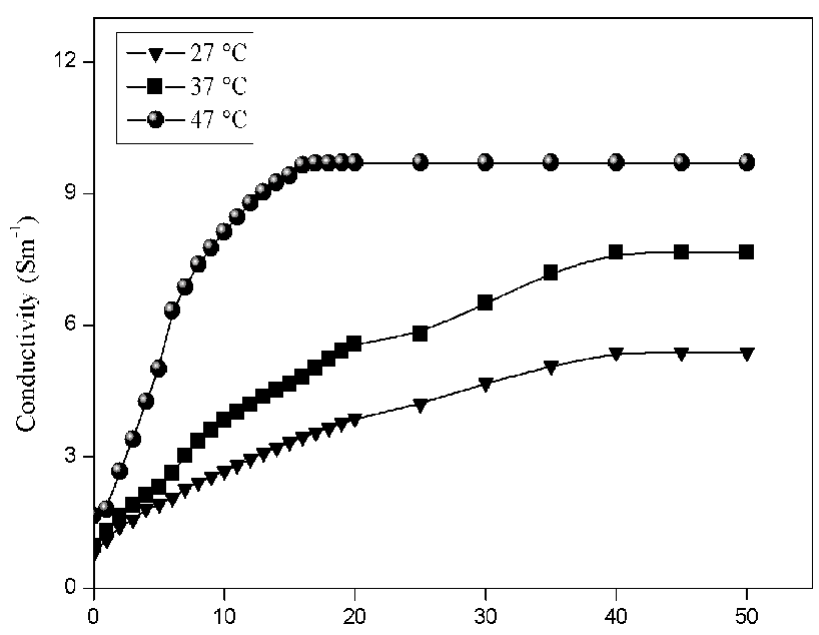

Figure 5: Swelling (\%) versus immersion time of formulated DP/LB-tablets at $37^{\circ} \mathrm{C}$. 


\begin{tabular}{|c|c|}
\hline Properties & Value \\
\hline Hardness $(\mathrm{kp})$ & $9.670 \pm 0.810$ \\
Friability $(\%)$ & $0.102 \pm 0.003$ \\
Weight $(\mathrm{g})$ & $0.502 \pm 0.002$ \\
Time disintegration (min) & $25.00 \pm 3$ \\
Diameter (cm) & $1.260 \pm 0.010$ \\
Thickness & $2.000 \pm 0.005$ \\
Humidity $(\%)$ & $1.75 \pm 0.020$ \\
\hline
\end{tabular}

Date are represented as mean \pm SD

Table 3: Technological Characterization attributes of the prepared tablet (mixture DP/LB).

et al. [21] and Zea et al. [22] concerning food tablets prepared with date (Phoenix dactylifera L.)/spirulina (Spirulina sp.) and guava/pitaya powders respectively.

Dissolution and kinetics modeling: Electrolyte content increases with dissolution time and temperature. All the curves present the same evolution of dissolution process with two distinct periods: the first phase of $15 \mathrm{~min}$. corresponds to the increase in the cumulated conductivity while the second equilibrium phase indicates a suspension of any transfer of matter (in terms of electrolytes). This last phase corresponds in fact to the complete dissolution of the tablet. Buckton and Efentakis [61,62] and Ferrero et al. [63] have obtained similar curves during the use of thermodynamic activation parameters to describe and characterize the mechanisms of released drug from hydrophobic matrices.

At $57^{\circ} \mathrm{C}$, the EC change is higher, compared with other temperatures. However, at the equilibrium phase $\mathrm{EC}$ is found to be 3.5 and 2.5 times higher than those at 27 and $37^{\circ} \mathrm{C}$ respectively. The effect of temperature on the conductivity agrees with the published studies [64] where the authors demonstrate that the leaching of inorganic dissolved solids in the solution increases with increasing temperature.

The modeling results of the release kinetics of TDS in the case of distilled water as dissolution media are recapitulated. Incontestably, for all temperatures: $27,37,47$, and $57^{\circ} \mathrm{C}$, Korsmeyer-Peppas model fit better the experimental data with $\left(\mathrm{R}^{2}=0.989\right.$ with $\mathrm{RMSE}<0.1$ and

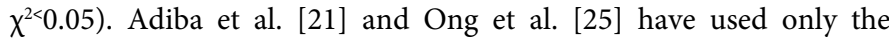
Korsmeyer-Peppas model and found a good fit. But, working on tablets from $80 \%$ pectin, Khule et al. [65] have found that among the four tested models, that of Korsmeyer-Peppas was the best. On the other hand, Baddam and Bandela [66] suggested that the Korsmeyer-Peppas model is suitable for predicting the dissolution times of several tablets.

The 0.447 value of the exponent $(n)$ for Korsmeyer-Pappas model at $27^{\circ} \mathrm{C}$ indicates that the mechanism of released ions from the tablets is of a Fickian type, controlled by diffusion mechanism. At higher temperatures, the calculated exponents $(n)$ were in the range from 0.601 to 0.606 (better for each temperature), indicating either an anomalous transport or non-Fickian mechanism. These results are in concordance with those of Cruz et al. [67] about polyethylene oxide/ primaquine matrix tablets which showed that the ions being released by both diffusion and erosion are controlled mechanism.

Effect of temperature: To the best of our knowledge, there are no reports available on the investigation of the temperature dependence of ionic transfer including food matrices. The attempts to model drug release profiles through the thermodynamic parameters are limited. However, Buckton and Francis [68] confirmed that is possible to study and describe the dissolution mechanism of drug released from a controlled oral dosage form, by use of the thermodynamic parameters of activation. It can observe that the zero order models leads to a maximal activation energy followed by both the Higuchi and first model. The low value is obtained in the case of the Peppas model $(17.272 \mathrm{~kJ} / \mathrm{mol})$. This value is very close to that $(18.3 \mathrm{~kJ} / \mathrm{mol})$ related for the diffusion drug process (sodium salicylate) from non-disintegrating hydrophilic matrices Touitou and Donbrow [69] and those reported by Ferrero et al. [63] in the case of caffeine released from hydrophilic matrices made of cellulose ethers. These authors have shown that the apparent Ea values $(14.4 \pm 4.0$ and $16.3 \pm 2.5 \mathrm{~kJ} / \mathrm{mol}$ for $\mathrm{pH} 6$ and $\mathrm{pH} 2)$ respectively. They have concluded that these values are low and not compatible with a swelling-controlled process mechanism which can be assigned to the dimensional change of the system during drug release.

\section{Conclusions}

Powders from Strawberry tree (Arbutus unedo L.) fruits, date (Phoenix dactylifera L.) fruits and their mixture with $1 / 2$ ratio were first investigated for some of their physical properties. Based on X-ray diffraction analysis, the powder mixture shows a crystalline structure, similar to that observed for date fruit powder. The results also revealed the good ability of the powder mixture for tableting by direct compression. In addition, it was found that among the four applied models, the Kosmeyer-Peppas better describes the experimental data of the dissolution kinetic of the tablets, the dissolution process being evaluated throughout the total dissolved solids via the electric conductivity measurement of the surrounding media. The temperature dependence of the dissolution process is studied from; it was estimated using Arrhenius equation. The latter allowed concretely to determinate the activation energy $(17.272 \mathrm{~kJ} / \mathrm{mol})$ using the rate constant of the selected model. Taking into account the nutritional and physiological potentials of the basic components of the analyzed powder mixture, the obtained tablets may be used as dietary supplement and/or as excipient in the pharmaceutical industry. Additionally, the physicochemical characterizations (toxic elements, behavior of tablets in various solutions simulating the physiological mediums, photochemical screening) are in the process of finalization and the results will be communicated in a future paper.

\section{Acknowledgements}

This work is supported by the thematic research agency in science and technology (ATRST, ex. ANDRU Algiers / Algeria) as part of an innovative project.

\section{References}

1. Nazarudeen A (2010) Nutritional composition of some lesser-known fruits used by ethnic communities and local folks of Kerela. Ind J Trad Knowl 9: 398-402.

2. Aberoumand A, Deokule SS (2009) Studies on Nutritional Values of Some Wild Edible Plants from Iran and India. Pak J Nutr 8: 26-31.

3. Feyssa DH, Njoka JT, Asfaw Z, Nyangito MM (2011) Wild Edible Fruits of Importance for Human Nutrition in Semiarid Parts of East Shewa Zone Ethiopia: Associated Indigenous Knowledge and Implications to Food Security. Pak J Nutr 10: 40-50

4. Boudjelal A, Henchiri C, Siracusa L, Sari M, Ruberto G (2012) Compositional analysis and in vivo anti-diabetic activity of wild Algerian Marrubium vulgare $\mathrm{L}$. infusion. Fitoterapia 83: 286-292.

5. Zheng J, Ding C, Wang L, Li G, Shi J, et al. (2011) Anthocyanins composition and antioxidant activity of wild Lycium ruthenicum Murr, Qinghai-Tibet Plateau. Food chem 126: 859-865.

6. Eromosele IC, Eromosele CO, Kuzhkuzha DM (1991) Evaluation of minera elements and ascorbic acid contents in fruits of some wild plants. Plant Foods Hum Nutr 41: 151-154.

7. Mahapatra AK, Mishra S, Basak UC, Panda PC (2012) Nutrient analysis of some selected wild edible fruits of deciduous forests of India: An explorative study towards non-conventional bio-nutrition. Adv J Food Sci Technol 4: 15-21.

8. Magaia T, Uamusse A, Sjöholm I, Skog K (2013) Dietary fiber, organic acids and minerals in selected wild edible fruits of Mozambique. Springerplus 2: 88.

9. Pallauf K, Rivas-Gonzalo JC, Del Castillo MD, Cano MP, Pascual-Teresa S 
(2008) Characterization of the antioxidant composition of strawberry tree (Arbutus unedo L.) fruits. J Food Compos Anal 21: 273-281.

10. Pawlowska AM, De Leo M, Braca A (2006) Phenolics of Arbutus unedo L. (Ericaceae) fruits: identification of anthocyanins and gallic acid derivatives. $J$ Agric Food Chem 54: 10234-10238.

11. Simonetti MS, Damiani F, Gabrielli L, Cossignani L, Blasi F, et al. (2008) Characterization of triacylglycerols in Arbutus unedo L. seeds. Ital J Food Sci 20: 49-56.

12. Rahman MSh (2007) Allicin and other functional active components in garlic: Health benefits and bioavailability. Int J Food Prop 10: 245-268.

13. Özcan MM, Haciseferogullari H (2007) The Strawberry (Arbutus unedo L.) fruits: Chemical composition, physical properties and mineral contents. J Food Eng 113: 1022-1028.

14. Alarcão-E-Silva MLCMM, Leitão AEB, Azinheira HG, Leitão MCA (2001) The arbutus berry: Studies on its color and chemical characteristics at two mature stages. J Food Compos Anal 14: 27-35.

15. Tawaha K, Alali FQ, Gharaibeh M, Mohammad M, El-Elimat T (2007) Antioxidant activity and total phenolic content of selected Jordanian plant species. Food Chem 104: 1372-1378.

16. Ayaz FA, Kucukislamoglu M, Reunanen M (2000) Sugar, non-volatile and phenolic acids composition of strawberry tree (Arbutus unedo $L$. var. ellipsoidea) fruits. J Food Compos Anal 13: 171-177.

17. Ruiz-Rodríguez BM, Morales $P$, Fernández-Ruiz V, Sánchez-Mata MC Cámara M, et al. (2011) Valorization of wild strawberry-tree fruits (Arbutus Unedo $L$.) through nutritional assessment and natural production data. Food Res Inter 44: 1244-1253.

18. Allane T, Benamara S (2010) Antioxidant activities of some common and wild fruits from Algeria. Phytother 8: 171-175.

19. Devla MN, Acharya SR, Acharya NS, Kumar V (2011) Dietary supplements: A legal status in India \& in foreign countries. Int J Pharm Pharm Sci 3: 7-12.

20. Murrieta-Pazos, Gaiani C, Galet L, Scher J (2012) Composition gradient from surface to core in dairy powders: agglomeration effect. Food Hydrocoll 26: 149158.

21. Adiba BD, Benamara S, Saidi N, Meksoud A (2011) Preliminary characterization of food tablets from date (Phoenix dactylifera L.) and spirulina (Spirulina $s p$.) powders. Powder Technol 208: 725-730.

22. Zea LP, Yusuf YA, Aziz MG, Ling CN, Mohd Amin NA (2013) Compressibility and dissolution characteristics of mixed fruit tablets made from guava and pitaya fruit powders. Powder Technol 247: 112-119.

23. Prakash SS, Patra ChN, Santanu Ch, Kumar PH, Patro VJ, et al. (2011) Studies on flowability, compressibility and in-vitro release of Terminalia Chebula fruit powder tablets. Ir J Pharm Res 10: 393-401.

24. Arama E, Michaud P, Rouffiac R, Rodriguez F (1989) Bioavailability of prolonged-liberation tablets of theophylline and paracetamol formulated in pulp from the fruit of baobab (Adansonia digitata L). Pharm Acta Helv 64: 116-120.

25. Ong MY, Yusof YA, Aziz MG, Chin NL, Mohd Amin NA (2014) Characterisation of fast dispersible fruit tablets made from green and ripe mango fruit powders. J Food Eng 125: 17-23

26. Benamara S, Aksil T, Boukhiar A, Megdoud Dj, Iguergaziz N, et al. (2012) Tabletting: Alternative way of valorization of agro resources. Proceeding of the Third International Scientific Symposium Agrosym, Jahorina (Bosnia).

27. Abbas-ksil T, Benamara S (2015) Modeling of the Dissolution Kinetics of Arbutus Wild Berries-Based Tablets as Evaluated by Electric Conductivity. Sains Malaysiana 44: 301-308.

28. European Pharmacopoeia (2008) 6th edn. European Treaty Series.

29. Carr RL (1965) Evaluating flow properties of powders. Chem Eng 72: 116-124.

30. Hausner HH (1967) Friction conditions in a mass of metal powder. Int J Powder Metall 3: 7-13

31. Yao H, Xu L, Han F, Che X, Dong Y, et al. (2008) A novel riboflavin gastromucoadhesive delivery system based on ion-exchange fiber. Int J Pharm 364 $21-26$

32. Frenning G, Ek R, Strømme M (2002) A new method for characterizing the release of drugs from tablets in low liquid surroundings. J Pharm Sci 91: 776-784.
33. Chantraine F, Viana M, Brielles N, Mondain-Monval O, Pouget C, et al. (2006) Parametric Study of Surfactant Effect on Mechanical and Dissolution Properties of Detergent Tablets. J Surfact Deterg 9: 267-277.

34. Mikac U, Demsar A, Demsar F, Sersa I (2007) A study of tablet dissolution by magnetic resonance electric current density imaging. J Magn Reson 185 103-109.

35. Gauza M, Kubisz L (2010) Electrical conductivity of fish skin collagen in the temperature range 290-380 K. Acta Phys Polon 118: 54-57.

36. Ahmed DM, Yousef ARM, Hassan HAS (2010) Relationship between electrica conductivity, softening and color of Fuerte avocado fruits during ripening. Agric Biol J North Am 1: 878-885.

37. Taiwo KA, Adeyemi $O$ (2009) Influence of blanching on the drying and rehydration of banana slices. Afr J Food Sci 3: 307-315.

38. Harland RS, Dubernet C, Benoit JP, Peppas NA (1988) A model of dissolution controlled, diffusional drug release from non-swellable polymeric microspheres. J Control Rel 7: 207-215

39. Higuchi T (1963) Mechanism of sustained-action medication. Theoretical analysis of rate of release of solid drugs dispersed in solid matrices. J Pharm Sci 52: $1145-1149$.

40. Gibaldi M, Feldman S (1967) Establishment of sink conditions in dissolution rate determinations. Theoretical considerations and application to nondisintegrating dosage forms. J Pharm Sci 56: 1238-1242.

41. Peppas NA (1985) Analysis of Fickian and non-Fickian drug release from polymers. Pharm Acta Helv 60: 110-111.

42. Atekwana EA, Atekwana EA, Rowe RS, Werkema DD, Legal FD (2004) The relationship of total dissolved solids measurements to bulk electrical conductivity in an aquifer contaminated with hydrocarbon. J Appl Geophys 56 : 281-294.

43. Ritger PL, Peppas NA (1987) A simple equation for description of solute release II. Fickian and anomalous release from swellable devices. J Contro Rel 5: 37-42.

44. Costa P, Sousa Lobo JM (2001) Modeling and comparison of dissolution profiles. Eur J Pharm Sci 13: 123-133.

45. Panda DS, Choudhury NS, Yedukondalu M, Si S, Gupta R (2008) Evaluation of Gum of Moringa oleifera as a Binder and Release Retardant in Tablet Formulation. Indian J Pharm Sci 70: 614-618.

46. Mehrotra A, Chaudhuri B, Faqih A, Tomassone MS, Muzzio FJ (2009) A modeling approach for understanding effects of powder flow properties on tablet weight variability. Powder Technol 188: 295-300.

47. Ahad HA, Meghana M, Navya K, Mallika B, Aaslesha A, et al. (2010) Designing and evaluation of Glibenclamide Azadirachta indica mucilage based controlled release matrix tablets. Der pharma Letter 2: 117-121.

48. Aouidi F, Dupuy N, Artaud J, Roussos S, Msallem M, et al. (2012) Discrimination of five Tunisian cultivars by Mid Infrared spectroscopy combined with chemo metric analyses of olive Oleaeuropaea leaves. Food Chem 131: 360-366.

49. Engelsen SB, Nørgaard L (1996) Quantitative vibrational spectroscopy on pectin's. Prediction of the degree of esterification by chemo metrics. Prog in Biotech 14: 541-548.

50. Khan S, Ramu G, Krishna G, Bhalgat C (2011) Tablet disintegrants activities of new starch from immature pepino fruits. J Sci Ind Res 70: 149-155.

51. Nakanishi K (1962) Infrared Absorption Spectroscopy. Nankodo Company: Tokyo: $30-42$.

52. Kamil MM, Gamal F, Mohamed GF, Mohamed SS (2011) Fourier Transforme Infrared Spectroscopy for Quality Assurance of Tomato Products. J Am Sci 7 559-572.

53. Alles MJL, Tessaro IC, Noreña CPZ (2013) Physicochemical characterization of Saccharides Powder Obtained from Yakon Roots (Smallanthus sonchifolius) by membrane technology. Braz Arch Biol Technol 56: 1024-1033.

54. Caparino OA, Tang J, Nindo Cl, Sablani SS, Powers JR, et al. (2012) Effect of drying methods on the physical properties and microstructures of mango (Philippine 'Carabao' var.) powder. J Food Eng 111: 135-148

55. Emeje M, Isimi C, Byrn S, Fortunak J, Kunle O, et al. (2011) Extraction and physicochemical characterization of a new polysaccharide obtained from the fresh fruits of abelmoschus esculentus. Iran J Pharm Res 10: 237-246. 
Citation: Abbas-Aksil T, Abbas M, Trari M, Benamara S (2016) Matrix Tablets from Algerian Lyophilized Berries (LB) (Arbutus unedo L.) Date (Phoenix dactylifera L.). Nat Prod Chem Res 4: 207. doi:10.4172/2329-6836.1000207

56. Niimura H, Yokoyama T, Kimura S, Matsumoto Y, Kuga S (2010) AFM observation of ultrathin microfibrils in fruit tissues. Cellulose 17: 13-18.

57. Ngwuluka NC, Idiakhoa BA, Nep El, Ogaji I, Okafor IS (2010) Formulation and evaluation of paracetamol tablets manufactured using the dried fruit of Phoenix dactylifera Linn as an excipient. Res Pharm Biotech 2: 25-32.

58. Arsyadi EA, Broto L, Kardono S (2007) Study of Coating Tablet Extract Non Fruit (Morindacitrifolia, L.) with Maltodextrin as a Sub coating Material. J Med Sci 7: 762-768

59. Dürig T, Fassihi R (2002) Guar-based monolithic matrix systems: effect of ionizable and non-ionizable substances and excipients on gel dynamics and release kinetics. J Control Release 80: 45-56.

60. Costa ART, Alves SF, Da Conceição EC, Garrote CFD, Paula JR, et al (2011) Dissolution test of herbal medicines containing Passiflora sp. Braz J Pharmacogn 21: 525-531.

61. Buckton G, Efentakis M (1990) The use of thermodynamic activation parameters and compensation analysis to model drug release from hydrophobic matrices. Int J Pharm 62: 157-163.

62. Khan S, Charhate K, Singhavi D, Yeole P (2013) Formulation and Release behavior of sustained release Stavudine Hydrochloride Matrix tablet containing Hydrophilic and Hydrophobic Polymers. Int J Drug Develop Res 5: 32-37.
63. Ferrero F, Massuelle D, Jeannerat D, Doelker E (2013) Towards elucidation of the drug release mechanism from compressed hydrophilic matrices made of cellulose ethers. III. Critical use of thermodynamic parameters of activation for modeling the water penetration and drug release processes. J Control $\mathrm{Re}$ 170: $175-182$.

64. Bayram M, Kaya A, Oner MD (2004) Changes in properties of soaking water during production of soy-bulgur. J Food Eng 61: 221-230.

65. Khule NR, Mahale NB, Shelar DS, Rokade MM, Chaudhari SR (2012) Extraction of pectin from citrus fruit peel and use as natural binder in paracetamol tablet. Der Pharmac Lettre 4: 558-564.

66. Baddam MSR, Bandela S (2013) Formulation and Evaluation of Albendazole Sustained Release Matrix Tablets Using Okra Gum. Int J Res Pharmaceut Biomed Sci 4: 1344-1353.

67. Cruz P, Bertol CD, Stulzer HK, Murakami FS, Costella FT, et al. (2008) Swelling erosion and release behavior of PEO/Primaquine matrix tablets. Pharmaceut Chem J 42: 413-418.

68. Buckton G, Francis MR (1987) Use of thermodynamic functions to describe the mechanism of drug release from a sustained release dosage form. J Pharm Pharmacol 39: 132.

69. Touitou E, Donbrow M (1982) Drug release from non-disintegrating hydrophilic matrices: sodium salicylate as a model drug. Int J Pharmaceut 11: 335-364. 